\title{
A Muslim Contribution to International Relations Theory: Aman (Peaceful Co-Existence and Mutual Respect) Theory
}

\author{
Abd al-Fattah M. El-Awaisi
}

Abstract

\begin{abstract}
In the last ten years, the world has witnessed much debate on new forms of the global phenomena of fundamentalism and extremism. It is clear that many view Muslims as "the other" or outsider and vice-versa; an attitude of "us and them", "our community and their community". The concept of a 'clash of civilisations' has become part of our everyday vocabulary. The objective of this article is namely to develop the theory of Aman (peaceful co-existence and mutual respect) as a Muslim contribution to normative considerations in international relations theory. It is found that the main four components of this theory are: the methodology of Tadafu'(counteraction), the concept of Adil (justice), the principle of not excluding others, and the constructive argumentation methodology. The theory has been tested and implemented by examining, in particular, Umar Assurance of Aman and the negotiations between Salah al-Din and King Richard I 'the Lionheart' of England over Islamicjerusalem in 1191. It is hoped that this theory could help place Muslim contributions in the epitome of global discourse of international relations theory, set the scene to advance the current research on the Muslim contributions to international relations theory including peace study and conflict resolution, and open up and promote intellectual and academic debate and understanding of this Muslim contributions to shed light on new lines of explanation. Although Islamicjerusalem is the most delicate issue of dispute between the current two conflicting parties, it is hoped that this theory will provide a better understanding for the world leaders who are trying to return peace to the region.
\end{abstract}

Keywords: Muslim contributions, Islam, aman theory, international relations theory, conflict resolutions, peace models, peaceful co-existence, mutual respect, multiculturalism.

\section{Introduction}

In the last ten years, the world has witnessed much debate on new forms of the global phenomena of fundamentalism and extremism. People are more aware of the intense political climate and clashes that have come to be known as "fundamentalism" or "extremism". What these terms mean exactly has yet to be defined, but it is the author's view that at the root of such phenomena lies in the disease of ignorance or extreme interpretation of texts. 
It is clear that many view Muslims as "the other" or outsider and vice-versa; an attitude of "us and them", "our community and their community". The concept of a 'clash of civilisations' has become part of our everyday vocabulary. However, the basis of any such clash is either sheer ignorance or an extreme interpretation of the religious scriptures or secular ideologies on which people found their beliefs and actions. Whichever way one looks at it, the author argues strongly that better understanding through education, in particular higher education, is the solution that will facilitate humankind to break free of the chains of ignorance and rise above extremism. Indeed, education is the most essential way to beat extremists, and to achieve peaceful co-existence and mutual respect. This is a challenge to all communities who should be able to respect each others' differences and have a common ground and a shared purpose. In this context, there is a general need to develop how Muslims view others. Moreover, on the basis of the current conflict in West Asia region, one can define Islamicjerusalem' ${ }^{1}$ history more in terms of conflict and exclusion than a common open place for peaceful co-existence and mutual respect.

However, this research is not to examine western contributions to international relations theory and the current debate after the 11 of September 2001 attacks, nor to develop Islamicjerusalem as a model for peaceful co-existence and mutual respect. This article is a serious and scholarly attempt to develop a new theory within normative considerations in international relations theory. In other words, the objective of this article is namely to develop the theory of Aman (peaceful co-existence and mutual respect) to be used in all levels of analysis, as a Muslim contribution to international relations theory within the discourse of "rethinking international relations" at theory and practical levels. In doing so, the author will test and implement his theory by examining, in particular, Umar Assurance of Aman; and the negotiations between Salah al-Din and King Richard I 'the Lionheart' of England over Islamicjerusalem in 1191.

In addition, the aim of this article is to present this theory to intellectuals, academics, and the wider public interested in peace studies and conflict resolution. It is hoped that this theory could help placing Muslim contributions in the epitome of global discourse of international relations theory, set the scene to advanced the current research on the Muslim contributions to international relations theory, raise new and interesting questions, and open up and promote intellectual and academic debate and understanding of this Muslim contributions to shed light on new lines of interpretation, explanation and prediction. However, this may be a provocative and challenging issue for those in academic and political establishments who are interested in the study of Islam and Muslims and who may not accept these results/findings on the basis that it goes beyond their political agenda and attachments, or for those who cannot go along with innovation and new ideas. Indeed, to advance such knowledge, understanding and approaches is to challenge long-established traditionalist an d Orientalist claims. Although Islamicjerusalem is the most delicate issue of dispute between the current two conflicting parties, it is hoped that this theory will provide a better understanding for the world leaders who are trying to return peace to the region. 


\section{Material and Method}

The author has adopted the interdisciplinary and multidisciplinary approaches in this research. In addition, he did not embark on his research with a defined theory of Aman (peaceful coexistence and mutual respect). Instead, his findings/results have emerged in the course of his examination and analysis of the data collected systematically throughout the process of this research, in particular his study of the core Muslim sources, Qur'an (Muslim Holy Book), and Sunnah (Prophetic traditions); and the famous historical document of Umar's Assurance of Aman to the People of Aelia (Islamicjerusalem) (El-Awaisi, 2000). This means that this theory was developed from the author long research on these Muslim sources. Moreover, the author has endeavoured, in his explanations, understanding, interpretations, to concentrate on and look with complete openness at most if not all of the aspects surrounding the issue under discussion, and focus on the key and fundamental ones related to the theory. He has also tried to take a comprehensive, realistic, inclusive and scholarly approach rather than a theological faith stand or one that is politically exclusive.

The author deliberately choice mainly to test and implement his theory within historical events, namely, Umar Assurance of Aman; and the negotiations between Salah al-Din and King Richard I 'the Lionheart' of England over Islamicjerusalem in 1191. This is due to the fact that, in the past several decades, there is a silent divorce between historians and social scientists. Indeed, the problem that we are experiencing a break or at the very least, a wide gap between them. The main concern of social scientists is theory building which could help to understand and interpret events. Therefore, they focus on building theories and attempt to generalize. However, for the most time, they are not interested to deal with historical research. On the other hand, historians are trying to understand the events within its own time, place and framework to prove there authenticity. However, most historians are not interested in developing theories or proposed models, or generalize in their studies of history. To bridge this gap and to contribute to a better understanding of course of events, there is a need to have a constant and contractive dialogue between social scientists and historians. Accordingly, one of the author aims is to prove that we can use history to test theories. In other words, this is an exercise in applying history for the purposes of social sciences' theorists.

In addition, this article depends mainly on Muslim core sources, such as the Qur'an and its commentaries, as well as on books of Prophet Muhammad's traditions, on historical sources and secondary references. Throughout the article, the author has chosen not to depend on any one English translation of the meaning of the Qur'an but to use several English translations. To compare these translations and choose the best, he refers to several of those available including those of: Abdullah Yusuf Ali (2003), Muhammad Muhsin Khan and Muhammad Taqi-ud-Din Al-Hilali (1996), Muhammad Asad (2003), M.A.S. Abdel Haleem (2004), and Thomas Cleary (2004). In most cases, he has chosen part of their translation of a particular text adding to it his own translation. 
Some available English translations suffered from the translators not understanding the original Arabic texts. To help understand some important Arabic texts and to re-examine the accuracy of these translations, both transliteration and translation were included. Moreover, when translating terminologies from Arabic into English, an attempt has been made by the author to strike a balance between the strength of expression in the original and its exact meaning. However, to avoid the mistranslating of any particular Arabic terminologies, the author employed an approach of not translating these into English but leaving them in their original Arabic language and gives his own understanding of the term. This should help to avoid any leading to different or strange understandings and interpretations. For example, the term Aman which could be translated as safety, does not give the right meaning of the term in Arabic. For the author, the term Aman means peaceful co-existence and mutual respect.

\section{Results/Findings and Discussion}

The Inputs of the Theory: Main key components

The main principles for the Muslim theoretical frame of reference towards dealing with others are based basically on the core Muslim sources, the Qur'an and Sunnah. It was mainly on these sources that the Muslims developed their conceptual and theoretical framework towards non-Muslims. Based on the core Muslim sources, the main key components of such a theory are: the methodological approach of Tadafu' (counteraction) and the concept of 'Adil (Justice), the principle of non exclusion, and the constructive argumentation methodology.

\section{Tadafu' (counteraction) methodology}

Muslim core teachings reject the philosophy of a conflict based on eliminating the other party so that the victor can have the stage to himself. This would mean in effect annulling the principle of plurality and diversity. However, the core Muslim sources, consider diversity and plurality to be the basis of everything apart from God. Indeed, diversity and plurality in nations, religions, cultures, races, and religious laws is part of the design of the universe. In respect of their cultural, religious, or gender differences, the Qur'an addresses humans and reminds them that they belong to the same family, ya a'yyuh al-nasu inna khalaqnakum min dhakarin wa untha 'O humankind! We created you all from a single pair of a male and a female' (Qur'an, 49:13). In addition, it is narrated that Prophet Muhammad said that 'You are all the children of Adam.' In another verse, the Qur'an says wa law shaa' a Allah laja'alakum ummatan wahidatan 'If God had so willed, He could surely have made you all human one single community (nation)' (Qur'an, 5: 48). From this point of reference, he 'made you into nations and tribes' wa ja' alnakum shu'uban wa qabaa'ila. The main purpose for this creation is li ta'arafu 'so that you should get to know one another' (Qur'an, 49:13), not that you may despise one another. On the bases of the Muslim core sources, the Qur'an in particular, the author argues that the first step in establishing a model for peaceful co-existence and mutual respect to identify and recognise diversity and plurality. 


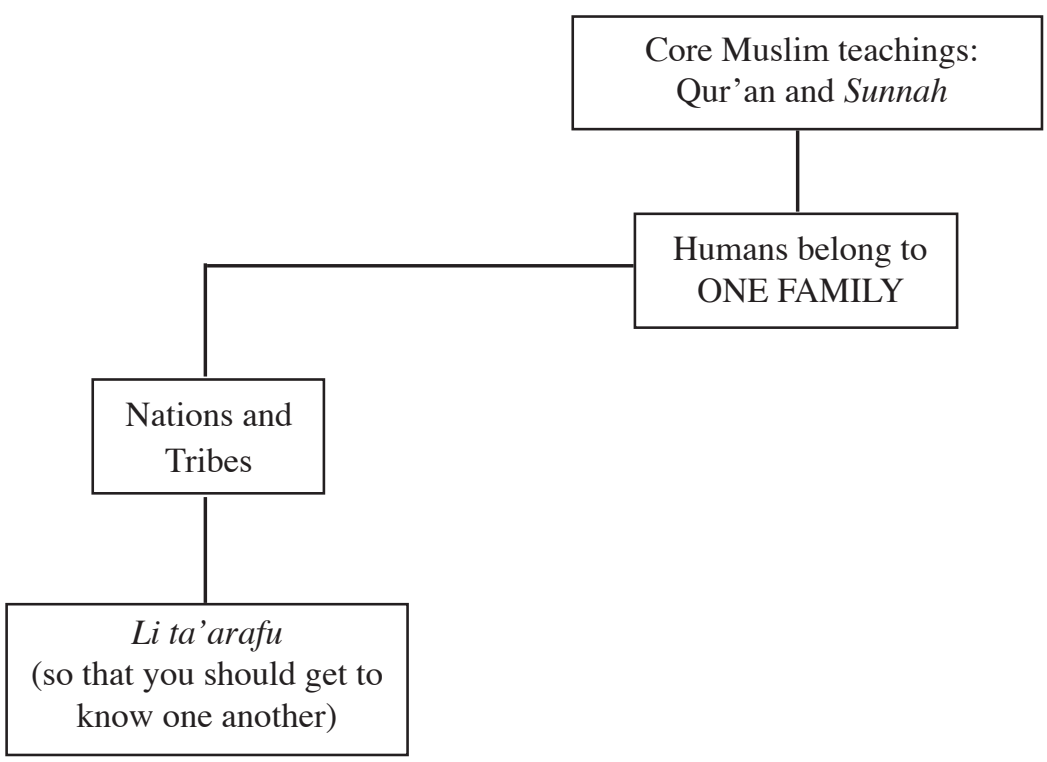

Diagram 1. Aman (Peaceful Co-existence and Mutual Respect) Theory.

As confirmation of this idea and a positive alternative to the philosophy of conflict, Islam favoured another method, namely Tadafu' (counteraction), as a means of adjusting positions using movement instead of conflict. For example, one verse of the Qur'an orders Muslims to be patient at the time of anger and to counteract those who treat them badly,

Wa la tastawi al-hasanatu wa la al-sayyi'ah, idfa' bi al-lati hiya ahsanu fa idhal-ladhi baynaka wa baynahu adawatun ka annahu waliyyun hamim. Wa ma yulaqqahaa ill al-ladhina sabaru wa ma yulaqqahaa illa dhu hazzin azim.

The good deed and the evil deed cannot be equal. Counteract the thou (evil) with what is better, and then the one, between whom and thyself there was enmity (will then become) as close as an old and valued friend. Yet (to achieve this quality) this is not granted to anyone but only those who are steadfast in patience and self-restraint - it is not granted to any but only those endowed with the greatest good fortune (Qur'an, 41: 34$35)$.

This conflict-free method is what Muslim teachings see as a means of preserving communities, societies, states, and the glob from the internal repression, despotism, and tyranny; and subservience to foreign powers. Tadafu' is not only to preserve Muslim's sacred places, but to preserve the sacred places of the rest of humanity, mentioned in the following Qur'anic verse about the chronology of religions: 
Wa lawla daf'u Allah al-nasa ba'dahum bi ba'din lahuddimat sawami'u wa biya'un wa salawatun wa masajidu yudhkaru fiha ismu Allah kathiran

... if God had not counteracted (Daf' $u$ ) some people by means of others, there would surely have been pulled down monasteries, churches, synagogues, and mosques, wherein the name of God is commemorated in abundant measure (Qur'an, 22: 40).

This means that, from a Muslim point of view, Tadafu' is the means of preserving a plurality of sacred places or the plurality of religions.

Concept of 'Adil (justice)

This methodology is linked to a very central concept in the core Muslim sources, the concept of 'Adil (justice) which encompasses all without discrimination between Muslim and nonMuslim at all times, places, and circumstances. Ecen at the time of war and disagreement, Muslims are required to apply this concept. For example, the Quran states:

\section{Wa la yajrimannakum shana'anu qawmin 'alla an la ta'dilu. 'idilu huwa 'aqrabu li al-taqwa.}

... and do not let the enmity and hatred of some people lead you away from justice, but adhere to justice, for that is closer to piety. (Qur'an, 5: 8).

The command to be just in this Qur'anic verse is general to all human without specifying any race or nation above another. The Prophet Muhammad warned against any unjust action by using a very clear and strong instruction to Muslims that they must deal with non-Muslims justly. He said, "He who hurts a Dhimi [non-Muslim] hurts me, and he who hurts me hurts Allah". It is interesting to note here the argument of one of great classical Muslim scholar, Ibn al-Qayyim al-Jawziyyah (n.d.: 16), who argued that "justice is the supreme goal and objective of Islam ... Any path that leads to justice is an integral part of the religion and can never be against it".

\section{The Principle of Non-Exclusion}

The claims that Muslims adopt the principle of excluding others to live with them, as discussed in the case of Jews barred from residence in Islamicjerusalem during the first Muslim Fatih (i.e., introducing new stage and vision), has not only not been historically proven (El-Awaisi, 2000), but also contradicts the core Muslim teachings which reject the notion of supremacy of one people or race over others. It contravenes the most basic Islamic principles concerning treatment of the People of the Book. Indeed, the reference in particular 
to the Jews is out of step, and even seems to clash with the main Muslim teachings, based on the Qur'an and Sunnah. For example, the Qur'an states that the treatment of non-Muslims, at individual, society, state, and regional and international systems, should be based on Birr and Qist:

God does not forbid you to deal kindly and justly (tabarruhum wa tuqsituu ilayhim) with those who have not fought you for your faith or driven you out of your homes. God loves those who act equitably (muqsitin). But God (only) forbids you to take as allies (tawallawhum) those who have fought against you for your faith, driven you out of your homes, and helped others in drive you out; any of you who take them as allies (man yatawallahum) will truly be wrongdoers (al-zalimun). (Qur'an: 60/8-9)

A young scholar, Maher Abu-Munshar, has examined several interpretations of this verse and presented a very interesting argument. He argues that the terminology Tabarruhum means not only to be kind to non-Muslims but to raise their treatment to the level of how one treats one's parent, with Birr (love and passionate). In addition, the terminology Tuqsitn includes providing non-Muslims with financial support. (Abu-Munshar, 2007: 16-21).

Indeed, in these two verses, the Qur'an lays down three conditions for Muslims to deal with humanity with Birr and Qist, namely that the others should not be: 1) fighting Muslims for their faith (Islam); 2) driving Muslims out of their countries; 3) helping others in driving Muslims from their countries. It is interesting to note that two of these three conditions are related to forcing Muslims to leave their countries. Sociologically, not having a home country, where you could return back any time, means in real term death, as you have been uprooted from your homeland. From talking to people who have been driven out of their countries, one could argue that the wrest thing in life is to be without home.

This means that, for Muslims, the origin of international relations - at all levels of analysis - is peace, and war is an exceptional case. In other words, lasting and durable peace is the foundation of international relations which revoked by aggression and injustice where driving people from their homes is its most manifestations.

As for the issue of the Jews; they were not at the time of the first Muslim Fatih at any stage of war with the Muslims in Islamicjerusalem or in any part of the world. As such, how could Umar Ibn al-Khattab exclude them from living in Islamicjerusalem? Although at the dawn of Islam, Muslims had had conflicts with the Jewish tribes in and around Madinah and later in Khaibar, they got along very well at all times afterwards, and especially in Islamicjerusalem. Moreover, Umar granted the Jews a special Assurance of Aman (El-Awaisi, 2000). In his attempt to discover the reasons behind the contemporary conflict between Muslims and Zionists, the contemporary leading Muslim Jurist, Yusuf al-Qaradawi (1997:13-14), argues that "Muslims did not fight Jews because they are Jews, but because they occupied the Islamic (Muslim) land in Palestine". 


\section{Constructive Argumentation Methodology}

One can argue that the best possible way of resolving a dispute in general and an intellectual disagreement or competing claims in particular between two conflicting parties should be through fair discussion. The Qur'an encourages Muslims to engage in discussion with all people in general and with the People of the Book in particular, through constructive argumentation, "argue with them bi-alati hia Ahsanin in the most beautiful (politest) manner" (Qur'an, 16: 125). The Qur'an lays down one condition for this constructive argumentation methodology, namely, that it should not be only in a beautiful way but in the "most beautiful manner".

According to the Qur'an, the starting point for any conflict resolution should be through constructive argumentation based on the power of knowledge and not from an arrogant position. In addition, constructive argumentation is a methodology encouraged by the Qur'an as a means for "constructive dialogue" and positive negotiation with others. A scholar in Qur'anic studies, Hussien Abdul-Raof (2003, p. 117), argues that "From a Qur'anic perspective, to argue is to negotiate an opinion; therefore, argumentation is a form of a constructive dialogue whether with an ally or an opponent". He clarifies his argument, adding that "to argue means to express an opinion with logical and substantiating reasons for or against something with the aim of persuading someone who can be an ally or an opponent in order to share one's own viewpoint".

Interestingly, from his examination of the Qur'an from a textual linguistics point of view, Abdul-Raof (2003: 119; 306-325) presents two patterns of Qur'anic argumentations, "thorough-argumentation" and "counter-argumentation". In the first pattern "a thesis is presented which represents its own viewpoint, followed by substantiation which introduces statements to validate the thesis, then a conclusion which supports the thesis and acts as a future back-up for the substantiation part of the argument". In the second pattern "a thesis is presented which represents an opponent's viewpoint, followed by opposition which introduces a counter-claim which are statements substantiating its own points of view, then a conclusion which presents a concluding statement that backs-up the opposition part".

\section{Outcomes of the Theory: Aman (Peaceful Co-Existence and Mutual Respect)}

The other Muslim core teaching sources conform to this methodology of Tadafu', the concept of 'Adil, the principal of not excluding others, and the constructive argumentation methodology. Both methodologies, concept, and principals emphasise the need to care for preserving human dignity and belongings. Preserving human dignity is very central in Muslim thoughts and attitude. In a very explicate and sharp manner, Umar asked his governor of Egypt, Amr Ibn al-Aas,

Mata Ista'batum al-Nas wa qad Waladathum Umahatuhum Ahraran? How could you have enslaved people, when their mothers have born them free? (Ibn al-Jawzi, 2001: 89). 
This very important international declaration was made by Umar when he received a complaint from an Egyptian Coptic man who was hit by Muhammad, the son of Amr Ibn al-Aas, who claimed to be "the son of honoured people". Umar called both Amr, his son, and the Coptic man to Madinah where he asked the Coptic man to hit Amr's son back in public, which he did.

One can argue that this preservation leads to the establishment of mutual respect and the elimination of fear, worries, suspicion, and distrust resulting from forcing people to change their religion "laa ikraha fi al-din, there is no compulsion in religion". (Qur'an, 2: 256). In another verse: "Whosoever will, let him believe, and whosoever will, let him disbelieve". (Qur'an, 18: 29); "Had your Lord willed, those on earth would have believed, all of them together. So, will you (O Muhammad) then compel mankind, until they become believers?" (Qur'an, 10: 99) The concept not only means rejecting the notion of compulsion in religions, cultures and politics but actually means the right of any individual, society, state to choices in respect of who they are. No doubt, the right of choices required two main elements, namely, freedom and alternative to choice from. This, indeed, promotes mutual respect, the appreciation and acceptance of others. This should secure Aman at all levels of analysis, and all kind of Aman, in particular, the political Aman and economical Aman which were mentioned very clearly in the following verse: "For the covenants (of security and safeguard enjoyed) by the Quraish. Their covenants (covering) journeys by winter and summer. Let them adore the Lord of this House, Who provides them with food against hunger, and with security against fear." (Qur'an: 106: 1-4)

This should lead not only to respect for non-Muslim rights but to granting them protection of lives and properties, freedom, security and support, and enabling them to become citizens and members of the society without interference in their culture and religion. Determining the status and rights of non-Muslims should act as a means to a peaceful co-existence and mutual respect among the different cultures and religions in a society. In this way, Ahmad al-Sharif (1976, p. 123), an Egyptian historian, argues, the ideal Muslim community is "an open community, where all human beings could live together on the basis of equality and justice”. Muhammad Said al-Buti (1999, p. 3-4), a contemporary leading Muslim jurist, argues that,

The Muslim state is not a monopoly of the Muslims alone... The Muslim system of statehood has a religious concept which the Muslims have to deal with and implement, just as it has an organisational legal concept which encompasses Muslims and non-Muslims. Each group interacts with it according to its status, either from a religious basis stemming from belief in Islam and its tenets, or from a social, legal standpoint based on law and order.

The first Muslim state implemented this concept clearly in its domestic and foreign dealings with non-Muslims. On the domestic front, for example, Prophet Muhammad wrote a 
document known as al-Sahifah "The Constitution of Madinah", in which he laid down the basis of relations with the Jews who lived in the bosom of the Islamic state. On the foreign front, we find examples in the contract that he concluded with the Magian people of Bahrain and the contract that he concluded with the Christian inhabitants of Najran. According to Muhammad Ibn Sa'd (who died 232AH/ 845 CE) (1985 (I): 358, when the Najran Christian delegation came to al-Madinah, the Prophet not only welcomed them in his Mosque but allowed them to say their prayers there. During their visit, they used to pray in one part of the Prophet's Mosque while the Muslims performed their prayer in another part.

What some early Muslim jurists subsequently wrote about dealing with the People of the Book indeed undermined this frame of reference. On the other hand, classical prominent Muslim jurists in particular, al-Nawawi in his book Rawdat al-Talibin (126-215/10), Ibn Qudama in his book AI-Mughni (358-357/9), and Abu Ubayd in his book Kitab Al-Amwal, have strictly rejected and warned against adopting the ruling which undermined the status of non-Muslims. Among the contemporary leading Muslim jurists who have written on the subject is al-Buti, who also agrees that the early rejected Muslim jurists' view "conflicts vehemently with the guidance of the Messenger of God in his words and deeds, just as it conflicts with what the righteous followers did, and with the piety with which God ordered the Muslims to behave towards the People of the Book in the Qur'an" (Al-Buti, 1999, p. 10). The author is inclined to argue that the contraventions, additions, or interpretations invented by some Muslim jurists were produced to please the rulers or match the general circumstances and socio-political developments that affected the position of the People of the Book during certain periods of history, especially the Abbasid state.

\section{Testing/Implementation of the Theory}

The best practical and clear implementation of this theory is in the form of what is well known in history as Al-Uhda al-Umariyya or Umar's Assurance of Aman to the People of Aelia. During Umar Ibn al-Khattab (d 24 AH/645 CE) historical visit to Islamicjerusalem five years after the death of Prophet Muhammad (12 Rabi' al-Awal 11 AH/ 6 June 632 CE), in Jumada I/II 16 AH/ June/July $637 \mathrm{CE}$ - he implemented all the four components of the Aman theory in his Assurance.

He laid down the foundation of fostering diversity and plurality in Islamicjerusalem. Not only did he recognise and appreciate others' presence in Islamicjerusalem, he accepted them and offered a framework to show that it could be shared with them. Indeed, as well as respecting and determining non-Muslim rights, he also took practical steps to grant them protection, safety and security for their rights, lives and properties. He granted them freedom, and enabled them to become citizens and members of the Islamicjerusalem society, without interference in their culture and religious life. In short, Umar not only identified, he also accommodated the presence and needs of his diverse citizens and established a system to protect their rich cultural diversity, identities and belongings. 
Indeed, Umar's model for a multicultural Islamicjerusalem was based on the core Muslim teachings, the Qur'an and Sunnah. Moreover, the methodology of Tadafu', the concept of 'Adil, and the principle of non-exclusion, together not only emphasise the recognition of others but also took great care to preserve the dignity of humans and what belonged to them as prescribed in the Muslim core teaching sources. By establishing this model, one can argue that Umar's aim was to preserve the human dignity of the people of Islamicjerusalem in status and rights regardless of their culture, religion, race and gender. This clearly manifested itself in the personal liberty, freedom and equality granted to the people of Islamicjerusalem in Umar's Assurance of Aman. Moreover, one may argue that this understanding and attitude to preserving human dignity and the recognition of others led Umar to implement the principles of mutual respect.

The foundations for managing the future relations between the three faiths were also laid down in Umar's Assurance. Although this was a practical application of the core Muslim teachings, the Qur'an and Sunnah, it was the major outcome of the first Muslim Fatih of Aelia. Indeed, it was the practical management initiative to implement the new vision for the region. In addition, it formed the cornerstone to manage and implement the new vision where Umar granted the people of Aelia an Assurance of Aman for themselves, their property, their churches, and their religion. Indeed, Umar's Assurance of Aman is a major pillar, an important frame of reference text, and a theoretical framework which laid down the foundation principles and the essential criteria to establish and manage peaceful coexistence and mutual respect in Islamicjerusalem multicultural society for the first time. It introduced, defined, and legislated the status and rights of non-Muslims in Islamicjerusalem and ensured a peaceful co-existence between the different communities there.

On this basis, Umar not only implemented these four components of this theoretical framework but demonstrated his protection practically during his first visit to Islamicjerusalem. Among the early events during this visit, which emphasised his keenness to protect non-Muslim holy places, was Umar's refusal to pray either in the Church of the Holy Sepulchre or its atrium when he was visiting the place and was invited to do so by Patriarch Sophronious. AbuMunshar (2007: 110) quoting Eutychius, Sa'id Ibn al-Batriq, reconstructed the recording of the conversation between Umar and Patriarch. Umar's justification for his refusal was

If I prayed inside the Church, it would have been lost by you and would have slipped from your power; for after my death the Muslims would take it away from you, together saying that 'Umar prayed here.

According to this account, it seems that Umar was not satisfied that his verbal explanation might be enough to convince the Muslims following his death not to change the church into a mosque. Umar wrote Sophronious a decree which read, 'The Muslims shall not pray on the stairs, unless it be one person at a time. But, they shall not meet there for a congregational prayer announced by the prayer call.' (Abu-Munshar, 2007, p. 110) 
Moreover, Umar also succeeded during his visit in establishing mutual respect with the Islamicjerusalem people. Sophronious trusted Umar with the Christians' holiest shrine when he entrusted him with the keys of the Church of the Holy Sepulchre. In addition to establishing this mutual respect, Sophronious secured the protection of the Church from Intra-Christian dispute. According to this account, Umar passed the keys to one of his companions, Abd Allah Ibn Nusaibah² (Abu-Munshar, 2007, pp. 111-112).

In short, in the seventh century, and in particular during the first Muslim Fatih of Islamicjerusalem, the land of hope provided the world with the famous document known as Umar's Assurance of Aman to the people of Aelia (Islamicjerusalem). This fundamental landmark of hope established a new system to manage diversity, laid the foundations for future relations, and led to reshaping the relationships between people of diverse faiths who inhabited the region, namely, Jews, Christians and Muslims. Indeed, Umar's Assurance was the jewel of the first Muslim Fatih of Aelia, and the beacon for developing Islamicjerusalem's unique and creative vision, nature, and model.

This marked the beginning of a new and distinguished era of safety, peace, stability, security, progress, development and prosperity. With his global feeling and a local touch, Umar was trying to resolve a local conflict with an international approach. In other words, he was 'thinking globally' and 'acting locally'. In short, Umar's global vision and local focus presented Islamicjerusalem as a model for peaceful co-existence and mutual respect.

With this peace among the different religions and cultures, stability was the obvious result. The whole region witnessed this very clearly. The author argues that Islamicjerusalem had always held the key to war and peace in the region. Whenever it has been blessed with peace, the whole region has enjoyed peace, security and stability. There is no doubt that settling the issue of Islamicjerusalem in a way that ensures justice and restores the rights of its people holds the key to world peace and regional stability.

One can argue that, to achieve global peace and stability, it is necessary to have peace and stability in Islamicjerusalem. Until this is achieved the entire world will not rest. Peace and stability in that region would bring about global peace and stability. Indeed, Islamicjerusalem acts as a centre for peace and for conflict in the world. Some might argue that this may be true for the Muslim Arab world but not for the rest of the world. The author argues that the formula is a global one. In the past, why did the farmers leave their land in Europe to go and fight during the Crusader period? Today, for example, when there is a conflict in that region, everyone pays the price of that war in one way or another: more taxes, higher petrol prices, etc.

What was the main basis of that original peace and stability? The author argues that it was the concept of 'Adil (justice). Justice is a pre-requisite for peace and stability. The formula which has been produced on the peace process negotiations for the current conflict in West Asia in the last decade is based on the Arab and the Palestinian point of view of 'Peace for 
Land', and on the Israeli point of view, 'Peace for Security'. The author argues that neither viewpoint is an appropriate formula. The exchange of land will not bring peace and security. In addition, imposing security will not bring peace. For the author, the formula based on this Aman theory and his understanding of the history of the region should be that neither peace nor security will be established without justice. So, the formula should be 'Peace for Justice' which will lead to preserving human dignity and mutual respect. In other words, justice is necessary before peace can be achieved.

Umar's Assurance of Aman not only rejected the notion of the supremacy of one people or race over others but presented Islamicjerusalem as a model both for peaceful co-existence and mutual respect; and for conflict resolution. As one of the main characteristics of Islamicjerusalem is its competing political and religious claims, it could be argued that it should be presented as a model for conflict resolution through constructive argumentation methodology as a means for a 'constructive dialogue' and positive negotiation with its conflicting parties. The adopting of this constructive dialogue methodology would open the way for conflict resolution.

The theory could even work in conflict situations and areas where there had been long centuries of war and exclusion. Even at a later stage, Salah al-Din was very faithful and committed to this inclusive vision. This prompted Salah al-Din's letter of reply to King Richard I 'the Lionheart' of England in October 1191 CE during the negotiations in the third Crusade. In an exclusive agenda, Richard claimed that "Jerusalem is the centre of our worship, which we shall never renounce, even if there is only one of us left" Salah al-Din replied by stating that Islamicjerusalem is the sacred legacy of the followers of all nations. He asserted the Muslim rights without denying the Christian rights in Islamicjerusalem and refuted Richard's claim that Muslims were invaders. In his reply, he stated that: "Islamicjerusalem is ours as much as it is yours. It is even more important for us, since it is the site of our Prophet's Night Journey and the place where the people will assemble on the Day of Judgment. Do not imagine, therefore, that we can waver in this regard" (Ibn Shaddad, 1964, p. 265; Little, 1989, p. 179).

Indeed, one other good example which tests this theory were the negotiations between Salah al-Din and King Richard I 'the Lionheart' of England during the third Crusade (1189-1193) . Their constructive dialogues not only led to resolving very complicated competing claims but ended with building confidence and establishing a good relationship and mutual respect between the two great leaders - which in their turn led to secure peace in one of the most conflicted areas. They succeeded in reaching an agreement, Al-Ramla Peace Treaty, which was signed on 23 Sha'ban 588AH/ 2 September 1192 CE.

According to Ibn Shaddad, during these negotiations, on 9 July 1192 CE Richard sent a message to Salah al-Din, "The King of England desires your love and friendship. He does not wish to be a pharaoh ruling the earth and he does not think that of you". He went further by handing Count Henry, Richard's nephew and "his troop over to your authority. 
If you were to summon them for execution they would hear and obey". This received a very positive response from Salah al-Din on 11 July, who replied "if you make this sort of overture to us, goodwill cannot be met with other than goodwill. Your nephew will be to me like one of my sons. You shall hear how I shall treat him" (Ibn Shaddad, 1964, p. 176 quoted by Abu-Munshar, 2007, pp. 166-167). Later on, when Richard met with Salah alDin's chamberlain (al-hajib), Abu Bakr, according to Ibn Shaddad, he told him "this Sultan of yours is a great man. Islam has no greater or mightier prince on earth than him ... By God, he is great" (Ibn Shaddad, 1964, p. 177 quoted Abu-Munshar, 2007, p. 168).

Stanley Lane-Pool (1985, p. 367) argues that “the secret behind Saladin's [Salah al-Din's] power lay in the love of his subjects. What others sought to attain by fear, by severity, by majesty, he accomplished by kindness". In his words to one of his sons, Salah al-Din revealed the source of his own strength was to

seek to win the hearts of the people, and watch over their prosperity; for it is to secure their happiness ... I have become great as I am because I have won men's (people) hearts by gentleness and kindness (Lane-Pool, 1985, pp. 367-368).

Abu-Munshar (2007: p. 173) concludes his discussion on these negotiations by arguing that, although Salah al-Din was a "determined fighter and a good strategist", he was a "model of chivalry; he was generous to his defeated enemies, kind toward Crusaders' women, and humane to captured prisoners of high rank. Once he had taken Islamicjerusalem he opened the city to pilgrims of all faiths" despite he had the power to do otherwise.

Indeed, one can argue that Islamicjerusalem, which has as one of its main characteristics competing political and religious claims, should be presented as a model for conflict resolution through constructive argumentation methodology as a means for a "constructive dialogue" and positive negotiation with its conflicting parties. The adopting of this constructive dialogue methodology in the past has opened the way for conflict resolution in the region. The late Michael Prior (1999, p. 2), a Christian academic theologian activist argued that "with such interest shown by each of the three religions, one might expect Jerusalem to be an a ideal place for inter-religious dialogue and sharing".

\section{Conclusion}

Although this article developed the Aman theory, the question which needs to be asked here is: what is the relationship between these four components of this theory, the methodology of Tadafu', the concept of 'Adil; the principle of non exclusion, and the constructive argumentation methodology? These four principals are intertwined key components of this theory. It is not possible to separate them as not one of them operates without the others. They are also linked and interlinked with their religious context. However, they do not operate simultaneously, with one simply reflecting the others. 
The following diagram, which the author developed in the process of constructing these relationships, could be used to understand this Aman theory.

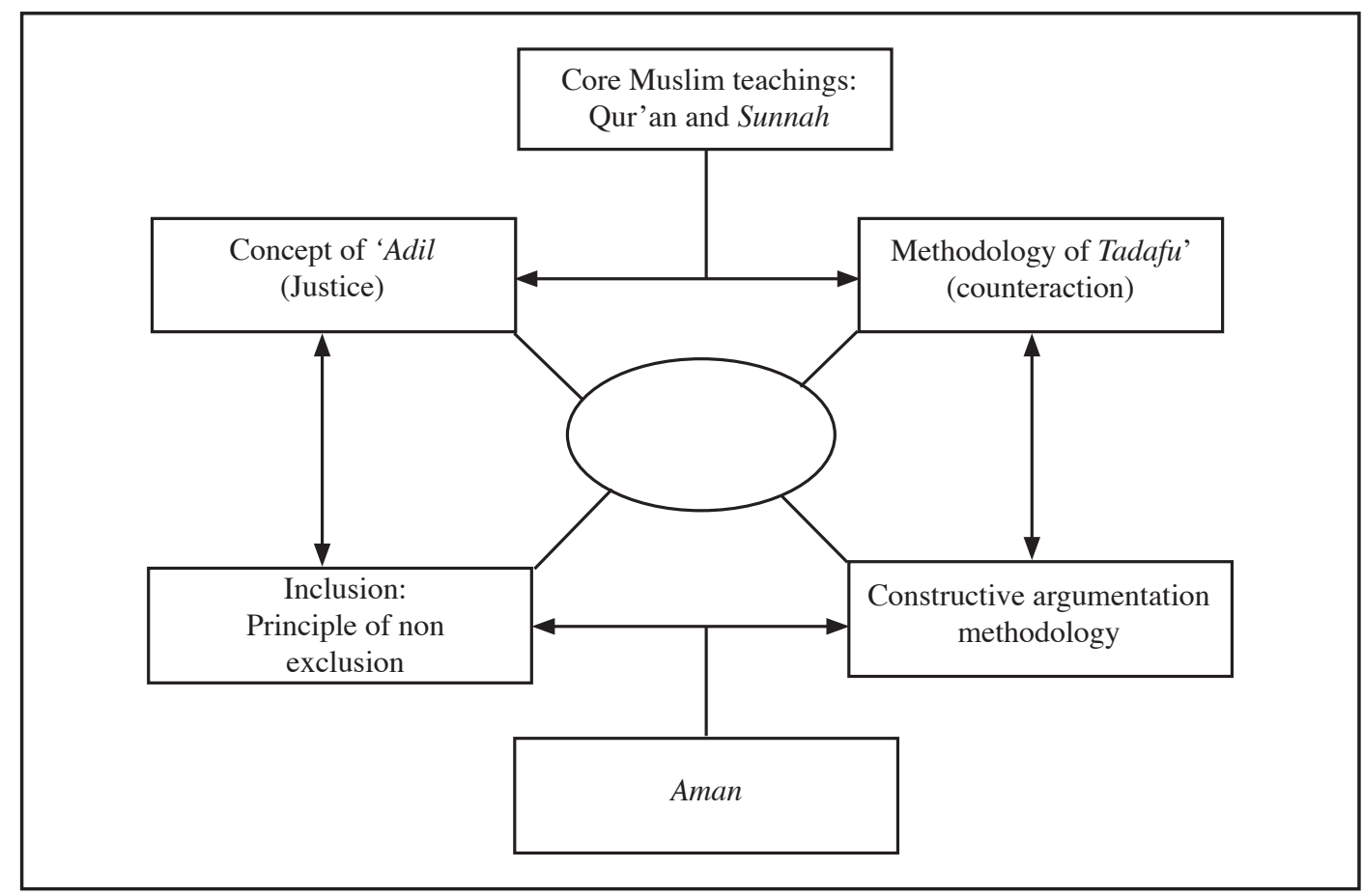

Diagram 2. Aman (Peaceful Co-existence and Mutual Respect) Theory.

Moreover, from testing and implementing this theory, it was obvious that Islamicjerusalem should be considered as a model for conflict resolution which consists of the four key interlinked elements.

\section{End Notes}

"Islamicjerusalem (one word) is a new terminology for a new concept, which may be translated into the Arabic language as Bayt al-Maqdis. It can be fairly and eventually characterised and defined as a unique region laden with a rich historical background, religious significances, cultural attachments, competing political and religious claims, international interests and various aspects that affect the rest of the world in both historical and contemporary contexts. It has a central frame of reference and a vital nature with three principal intertwined elements: its geographical location (land and boundaries), its people (population), and its unique and creative inclusive vision, to administer that land and its people, as a model for multiculturalism, cultural 
engagement and Aman (peaceful co-existence and mutual respect)." See the original definition in Abd al-Fattah El-Awaisi (2007: 11).

2 Although this account was not mentioned in any early sources, Abu-Munshar's satisfaction with its authenticity is based on the fact that the keys are still in the hands of the Al-Nusaibah family. (Abu-Munshar, 2007: 111-112).

3 With her back ground in Political Sciences, the author gave Ramona Ahmed Ibrahim (Egypt), one of the taught Master's students in Islamicjerusalem Studies at Al-Maktoum Institute for Arabic and Islamic Studies, a draft copy of this Article (before it was finalised) and encouraged her to conduct her Master's dissertation on Islamicjerusalem as a Model of Conflict Resolution: A Case Study of the Negotiations between Salah al-Din and Richard 1 the Lionheart (December 2005).

\section{References}

Abdel Haleem, M. A. S. (2004). The Qur'an: a new translation. Oxford: Oxford University Press.

Abdul-Raof, Hussein. (2003). Exploring the Qur'an. Dundee: Al-Maktoum Institute Academic Press, Scotland.

Abu-Munshar, Maher. (2007). Islamic Jerusalem and its Christian: A history of tolerance and tensions. London: I B Tauris.

Asad, Muhammad. (2003). The message of the Qur'an. England: Book Foundation.

Al-Buti, Muhammad Said. (1999). Mu'amalit al-Dawlah al-Islamiyyah li ghaiyr alMuslimin: al-Quds Namwudhajan. Journal of Islamicjerusalem Studies, 1 (3).

Cleary. (2004). The Qur'an: New translation. USA: Starlatch Press.

El-Awaisi, Abd al-Fattah. (2000). Umar's assurance of safety to the people of Aelia (Jerusalem): A critical analytical study of the historical sources. Journal of Islamic Jerusalem Studies, 3 (2).

El-Awaisi, Abd al-Fattah. (2007). Introducing Islamicjerusalem (Scotland: Al-Maktoum Institute Academic Press).

Ibn al-Qayyim al-Jawziyyah. (n.d.). Al-Turuq al-Hukmiyyah fi al-Siyasah al-Shar'iyyah Muhammad Jamil Ghazi, Matba’at al-Madaina (Ed.). 
Khan, Muhammad Muhsin \& Al-Hilali, Muhammad Taqi-ud-Din. (1996). Interpretation of the meaning of the noble Qur'an. Saudi Arabia: Dar-us-Salam.

Ibn al-Jawzi, Abu al-Faraj Abd al-Rahman Ibn Ali (Ed.) (2001). Sirat wa Manaqb Amir alMu'minin Umar Ibn al-Khattab. Cairo : Dar al-Da'wah al-Islamiyyah.

Ibn Sa’d, Muhammad. (1985). Al-Tabaqat al-Kubra (Beirut), vol. 1.

Ibn Shaddad, Baha' al-Din. (1964). Sirat Salah al-Din al-Ayoubi: AI-Nawadir al-Sultaniyya wa al-Mahasin al-Yusufiyya. Cairo, III.

Lane-Poole, Stanley. (1985). Saladin and the fall of the kingdom of Jerusalem. London: Dare Publishers.

Little,. P. (1989). Jerusalem under the Ayyubids and Mamluks. In K. J. Asali (Ed.), Jerusalem in History, Essex Scorpion: Publishing.

Prior,. (1999). Christian perspectives on Jerusalem. Journal of Islamicjerusalem Studies, 3 , (1).

Al-Qaradawi, Yusuf. (1997). Al-Quds fi al-Wa'yi al-Islami. Journal of Islamicjerusalem Studies 1 (1).

Al-Sharif Ahmad. (1976). Dirast fl al-Hadarah al-Islamiyyah. Cairo.

Yusuf Ali, Abdullah. (2003). The meaning of the Holy Qur'an. Leicester: Islamic Foundation. 
